International Journal of Linguistics, Literature and Translation

ISSN: 2617-0299 (Online); ISSN: 2708-0099 (Print)

DOI: 10.32996/ijltt

Journal Homepage: www.al-kindipublisher.com/index.php/ijltt

IJLLT

\title{
Linguo-Stylistic Analysis of Sarcasm in American Granddaughter
}

\author{
Abbas Lutfi Hussein ${ }^{1}$, Nadia Majeed ${ }^{2}$ and Rusul Abdel Kareem Atu ${ }^{3} \square$ \\ ${ }^{1}$ Assistant Professor, Mutansiriyah University, College of Arts. Iraq \\ ${ }^{2}$ Assistant Professor, Middle Technical University, Technical instructors Training Institute, Iraq \\ ${ }^{3}$ University of Misan, College of Education for Human Sciences, Iraq \\ $\square$ Corresponding Author: Rusul Abdel Kareem Atu, E-mail: pyytopes97@gmail.com
}

\begin{abstract}
ARTICLE INFORMATION
ABSTRACT

Received: 11 September 2021

Accepted: 05 October 2021

Published: 30 November 2021

DOI: 10.32996/ijlt.2021.4.11.9

Senses to express different intentions. senses to express different intentions. Inaam Kachachi makes full use of linguistic and figurative tools to express her sarcastic events and situations. Thus, this paper investigates the linguo-stylistic use of sarcasm in Kachachi's 'الحفيدة الامريكية' (American Granddaughter), focusing on the purposes behind the use of sarcasm in this

KEYWORDS

Linguo-stylistic, Sarcasm, American novel. Twenty extracts have been selected to be lingo- stylistically analyzed in terms of Leech and Short's (2007) model. The paper concludes that Kachachi utilizes lexical, grammatical, and figurative devices to depict her sarcastic events and circumstances.
\end{abstract} Granddaughter, Inaam Kachachi

\section{Introduction}

American Granddaughter, a novel by an Iraqi author Inaam Kachachi, depicts the American occupation of Iraq through the eyes of a young American-Iraqi woman, who returns to her country as an interpreter for the US Army. Through the narrator's conflicting emotions, the tragedy of a country is portrayed, having battled to emerge from dictatorship, then finds itself under foreign occupation and takes from irony a tool to reveal the satirical representation that the coalition soldiers make, mocking the traditions of the country. Ironically, it is the American dream itself that compels Zeina to advance to Iraq to work as a translator for the US Army. The prospect of moving out of Detroit's miserable Seven Mile and securing a down payment for a bigger home in Southfield, buying a new car, and putting her drug-addicted brother into rehab - all these events are important to Zina. The stylistic analysis has been exploited to reveal the different ways sarcasm is manipulated in the novel American Granddaughter. It seems that Kachachi often resorts to various linguo-stylistic devices to express herself and to attain the purposes behind issuing sarcastic scenes. Thus, the following pages are devoted to the presentation of a summary of American Granddaughter, the concept of sarcasm and its overlapping terms, the concept of stylistics, and its subdivisions, focusing on the linguo-stylistic type.

\section{American Granddaughter: Synopsis}

Zina, an Iraqi citizen, due to circumstances, migrated with her family to America. One day, a war broke out in Iraq after the fall of Saddam, and the Americans entered Iraq. They needed translators for them in Iraq. Zina decided to apply for this job, as it was an American dream for Zina in order to raise money to improve her life. Zina approved, collected her things, and went to travel to Iraq with a group of soldiers of different nationalities. Her grandmother knew that Zina had arrived in Iraq, yet she was not aware of her work with the US army. She was not reassuring, so she insisted on meeting her. When she saw her, she felt that she was working with the US army, but Zina denied that. Zina felt uneasy that her grandmother was against the American army in Iraq. Later, Rahma fell ill and decided to take Zina for treatment in Jordan with a person named Muhaimin. There, Zina loved Muhaimin very much, but Muhaiman was staying away from her because he was looking at her as his sister (they were breastfed by the same women); Zina did not care about that. He was a dominant communist against the US military and viewed the US military as hostile. After Rahma finished her treatment, they returned to Iraq, and Zina returned to her headquarters. She could not meet Muhaimin, but she was thinking about him a lot. Rahma became seriously ill, especially after she was deeply saddened by Zina's work with the US Army, and her life ended in death. Zina grieved her grandmother a lot. Rahma died due to her grief at Zina's joining the US army. Zina's contract with the US Army was over and she decided to return to America broken and full of sadness and emotion.

Copyright: (C) 2021 the Author(s). This article is an open access article distributed under the terms and conditions of the Creative Commons Attribution (CC-BY) 4.0 license (https://creativecommons.org/licenses/by/4.0/). Published by Al-Kindi Centre for Research and Development, London, United Kingdom. 
She no longer knew any news about Muhaimin, so she decided to delete his messages. Her story ended by saying that she had always wanted to get away from this feeling of home. Lately, she realized the meaning of home with a saying that her father repeated: "I will give my right hand if I forget Oh Baghdad."

\section{Sarcasm}

In a particular term, sarcasm is an expression, in which the "intended meaning is the opposite of actual spoken words" (Burton, 2009:78). Sarcasm is the deliberate attempt utilized to indicate, question, or ridicule attitudes and beliefs by using words or gestures in ways that contradict their natural meanings. It essentially depends on the listener, being that the speaker does not mean what is being said. In the case of sarcasm, often the gap between what is said and what conversation participants meant is created; it is usually filled by the listener due to several integrated factors, i.e. socio-cultural norms, contextual, pragmatic, and linguistic knowledge. Perhaps because this kind of pragmatic sarcasm occurs so commonly, it does not usually fall within the range of phenomena that the grammarian feels obligated to account for (Cardona, 2002: 358).

Relationally, Attardo (1999) defines sarcasm as "a type of sarcasm that is very aggressive, with clearer signs/signals and a clear intent." Similarly, MacDonald (1999: 486) affirms that sarcasm is "a form of sarcastic speech commonly used to convey implicit criticism to a particular victim as its target". However, over the years, there has been no consensus on whether irony is essentially the same thing, with superficial differences, or whether they are significantly different.

Dauphin (2000) notes, based on what John Hyman claims, that sarcasm can be used unintentionally and unconsciously, and situations can also be sarcasm. However, sarcasm must be intentional and conscious. In addition, the big difference for him is that situations cannot be sarcastic, while people can. According to Toplak (2000), there are many factors that influence the use, or degree of irony, in everyday language: exaggeration, the nature of the speaker, the speaker's relationship to the victim, the intensity of criticism, and whether or not criticism is present, made in the private sector or in front of the public. However, in McDonald's (1999:506) view, there is one key factor related to sarcasm: it is "a form of sarcastic speech commonly used to convey implicit criticism with a particular victim as its target."

\section{Sarcasm \& Overlapping Concepts}

Sarcasm has been utilized in different fields (social, political, religious ...etc.) to predict different types of meanings; therefore, there have been some terms overlapping with sarcasm. On one occasion, it can be used interchangeably with humor, in another with irony, yet in a third with satire. Thus, the following pages are devoted to showing the relatedness between sarcasm and the associated concepts.

\subsection{Humor}

The word "humor" is often used to mean liquid, including body fluids. Ancient doctors asserted that an individual's well-being depended on the balance between four such fluids: blood, sputum, black bile, and yellow bile. When these bodily fluids are disproportionate, various personality traits appear; Excess blood, for example, makes one an optimist or a pessimist. In this way "humor" was associated with the idea of a person whose temperament deviates from the norm. These people were considered cranky (Carroll, 2014).

The Oxford English Dictionary (2009, s.v. humor) defines humor as "the kind of work, speech, or writing that arouses entertainment; fun, oddity, jocularity, comicality, and facetiousness." Elaborately, humor is also taken to mean "the ability to perceive what is funny or interesting, or express it in speech, writing, or any other composition; or humor to imagine or address a topic" (ibid).

Based on the psychological state of humor, Meyer (2000) defines humor as a cognitive state of fun. Focusing on an appreciation of humor, Weisfeld (1993: 142) defines an appreciation of humor as "a distinct and enjoyable effect often accompanied by laughter." Laughter is the most "obvious behavioral expression of humor", as it includes a distinct "behavioral pattern that also has psychophysiological associations". Ruch and Ekman (2001) describe laughter as an expressive sound signal which provides an overview of laughter in terms of breathing, expression, facial movement, body movement, mechanisms, and element definition. In line with Weisfeld (1993), humor-induced laughter is associated with a pleasant emotional state associated with joy and joy.

Attardo et al. (2013) affirm that humor research has standardized the use of the comprehensive term "humor" to refer to any form of communicative behavior intended or interpreted as intended or interpreted as intended to elicit entertainment, joy, laughter, or associated feelings of joy, and the depiction of comedy and similar states of mind. By definition, "humor" is intended to include any form of this behavior, without any attempt at further differentiation. Under this term, humor includes most uses of irony.

Traditionally, Plato asserts that the laughter that accompanies humor is directed at vice, that is, we laugh at people who fail to follow the Socratic adage, 'know yourself, and who deceive themselves instead, imagining that they are wiser than them, or stronger or taller or braver. Thus, for Plato, amusement contains an element of malice. Plato expresses his distrust of humor. He fears that his world 
leads to first of what humor calls " incomparable laughter " and of course Plato was suspicious of anything that contributed to the lack of rational self-control(Carroll, 2014....).

Martin (2007) summarizes humor as (1) the ability to understand jokes and other propaganda stimuli, (2) an expression of humor and cheerfulness, (3) the ability to make humorous comments or have humorous perceptions, (4) an appreciation of different types of jokes and cartoons Animations, and other humorous material, (5) actively searching for sources that provoke laughter (for example, comedy), (6) memorizing jokes and funny stories in as well as (7) a tendency to use humor as a coping mechanism. Thus, Martin (2007) describes humor as an attribute of a person rather than a statement.

Sarcasm is often a form of humor. If we, following Stephen Leacock and many other brilliant researchers and practitioners, define humor as a contradiction, then the humor in satire resides in the contrast between the speaker's flat or sympathetic words and his hostile intentions (Haiman, 1998: 21). Stieger et al. (2011) refer to sarcasm as a form of aggressive humor. Thus, the peculiarity that makes sarcasm a special case of humor is the element of sarcasm. But, all humor may not intend to ridicule.

\subsection{Irony}

Irony and sarcasm are very closely related and occur on a continuum of aggression: irony is less aggressive, sarcasm is more so; for all practical purposes, they cannot be reliably differentiated. Extreme cases, such as overtly aggressive, biting sarcasm, and positive or gentle irony, can be identified as such, but intermediate cases cannot be differentiated. This is due to the fact that the concepts "irony," "sarcasm," as well as "humor," "wit," "satire," etc. are folk concepts that have existed for centuries and in some cases millennia, and have been used in a variety of situations, contexts and even meanings. To be fair, there have been several proposals to distinguish irony from sarcasm. For example, Haiman (1998) claims that irony can be unintentional while sarcasm cannot. Furthermore, according to Haiman (1998), irony may be situational, whereas sarcasm cannot. Sperber and Wilson (1981) distinguish between irony and sarcasm on the basis that irony would echo the speaker's own words, whereas sarcasm would echo another speaker's words. However, these claims, as well as others, ultimately fail to convince, for a variety of reasons, but primarily and centrally because they do not provide reliable criteria for analysis (Gurillo \& Ortega, 2013:40).

Sarcasm has typically played a supporting role in the pragmatic scene: the main purpose of analyzing sarcasm has been to shed light on the study of irony. Thus, analyses of sarcasm have traditionally been an appendix to theories of irony. Irony and sarcasm appear inevitably bound to each other in the field of pragmatics. Nonetheless, the relationship between the two phenomena remains unclear and the theoretical debate is based on a pre-theoretical confusion: the distinction between irony and sarcasm is unclear among natural speakers, and the differences are accentuated when we compare different cultures or linguistic communities (Garmendia, 2018: 127).

Relatedly, John Haiman (1998:20) writes that there is an extremely close connection between sarcasm and irony, and literary theorists in particular often treat sarcasm as simply the crudest and least interesting form of irony. First, situations may be ironic, but only people can be sarcastic. Second, people may unintentionally be involved in ironic situations, but sarcasm requires intention. It is essential to sarcasm that the irony in the message is being intentionally used as a form of verbal aggression.

\subsection{Satire}

There are many ways of looking at life: sarcasm is one of them. Responding to the world with a mixture of laughter and indignation may not be the best method, nor is it most likely to result in good deeds or great art; but it is the way of satire. Satire is referred to as "the use of ridicule, irony, sarcasm, etc. to expose, attack or ridicule vices, stupidity, etc." (Hodgart, 1969: 7). Satire is dedicated to exposing the human folly and its goal is to inspire critical thinking and rational social engagement. It is often accompanied by irony, parody, and wordplay. It is regularly mixed with sarcasm, irony, and ridicule. These different comedic and critical styles are often found side by side, which means that a comedian might make a sharp point of sarcasm, one moment to turn around and sarcastically attack someone the next time (McClennen, \& Maisel, 2016: 108).

\section{Stylistics}

Before indulging in the definition of stylistics, it is essential to disclose the relationship between style and stylistics. Style is a technique, artistic creation, or method of using anything by special means to reflect a particular meaning, starting with the simplest definition given by Verdonk (2002:3), style is a "distinct linguistic expression and stimulating choice, among other possibilities". Along the same line, De Beaugrande and Dressler (1981: 16) assert that despite the diversity of approaches, there is agreement that style is a consequence of the distinct choices of presentation options for a text or group of texts. (i.e.) the choices the speaker/writer makes among the phonetic, grammatical, and lexical sources in his language.

Significantly, Abrams (2009:302) points out that style as a 'linguistic expression' is one type of mode of interpretation, and each textual product creates all the objective characteristics of that text collectively with the intent of both the speaker and the listener, on vital factors such as intensity, metaphor, word choice, specific structure, sound and rhythm pattern, etc. 
Traditionally, stylistics has been confused with literary criticism, so designers wish to avoid the ambiguous and impressionistic conclusion manipulated by literary critics, and the formal use of language, emphasizing in their work on objective interpretation. In this respect, stylistics examines the entire text as a unit but not a block of sentences connected together (Fowler, 1991: 68). In Widdowson's (1975:3) words, stylistics is "the study of literary discourse from linguistic orientation." He describes stylistics as a bridge between language and literature and literary criticism with linguistics.

As a branch of linguistics, stylistics is concerned with "the methods of selecting and implementing linguistic, non-linguistic or artistic means and expressive means in the communication process". In general, it consists of two categories: linguistic (linguistic) and literary style. In this regard, stylistics studies "types of language, their characteristics, principles underlying selection, dialogue, dialect, register, etc." (Mistrik 1985, quoted in Missikova, 2003: 15). In general, in any text, the function of style is to determine "how language serves a particular technical function" (Leech, 1969:2). However, there are three main types of stylistics:

A. Literary stylistics is devoted to explaining the message of interpreting and evaluating "literary writings as works of art". It tends to investigate "the peculiarities of the literary genre, literary direction, means of artistic expression and the imaging system". Taking into account the writer's biography, the "aesthetic values and world perception" and the unique manipulation of linguistic and imaginary resources are taken into consideration in stylistic analysis, being able to choose "knowledge of the history of literature in the process of interpretation" (Galperin, 1977: 9).

B. Decoding method is a discipline that deals with "the features of linguistic speech that aim to impose the way of thinking of the encoder on the decoder". In this respect, the text can be interpreted in such a way as to govern its "decoding" (Riffaterre (1983: 6), and as a result, "acts on the reader as much as on the reader". He adds that "the contrast between the two leads to a stylistic effect" (ibid: 7). In practice, the writer chooses a part of reality and encodes his ideas/message through linguistic means, "symbols, etiquette symbols" or various other ways of condensing information. Thus, it can be said that the style of decoding entails "different symbols and literary styles of decoding for different linguistic levels".

C. Linguo-stylistics is the investigation of a text or discourse from a linguistic point of view. In fact, it deals with the linguistic matters used in the text that revolve around the basic meaning achieved through linguistic means. It mainly deals with "language symbols", their intended meaning, and how symbols and meaning are constructed. In other words, it focuses on the discovery and interpretation of "expressive and stylistic means" (Galperin, 1977:9). Interestingly, the aim of this paper is to divulge the linguostylistic features of sarcasm in American Granddaughter, focusing on the linguistic means utilized to highlight the function of sarcasm in this novel.

\section{Methodology}

The study involves the linguo-stylistic analysis of sarcasm in American Granddaughter. The analysis is carried out following the heuristic checklist of linguistic and stylistic categories presented by Leech and Short (2007). The checklist provides a 'systematic basis' for the collection of relevant linguistic data from the text for the purpose of stylistic evaluation and offers levels for analyzing linguistic choices made by the novelist. These levels include lexical, syntactic, and semantic features and figures of speech. Leech and Short (2007) point out that while the list itself is a selective one, leaving out a lot of detail, it allows the reader to reach the significant and relevant features of the text through a linguistic survey.

\section{Leech and Short's (2007) Model}

Leech and Short (2007: 60) draw an analytic model through a checklist of linguistic categories. They first assume a set of linguistic categories that are understandable to language beginners and applicable to literary or non-literary contexts, and secondly, with respect to the term 'grammar' they adopt the views and grammar of Quirk et al. (1985), and third, they presuppose the use of literary devices (metaphor, metonymy, onomatopoeia, etc.) and include them as leading phenomena. There is no perfect way to propose a stylistic analysis to the conservatives and to identify all the important features, yet each text has a technical result on the whole, and this shows the way for the linguistic aspects to be put into the whole. Furthermore, they (ibid: 61-64) assume their inferential model as they call it, consisting of a checklist with four headings: lexical categories, grammatical categories, speech forms, coherence, and context. They justify the excess of semantics as a separate class that can be accessed via other classes, or in other words, all classes interact with semantics.

\section{Proposed Model}

Based on the discussion above, the linguistic level proposed in this study includes two main phases: (1) linguistic analysis (grammatical, semantic, and lexical) and (2) figurative devices (simile, metaphor, parallel, repetition, antithesis, rhyme, and personification). These two stages are used to uncover the stylistic behavior of sarcasm in American Granddaughter. 


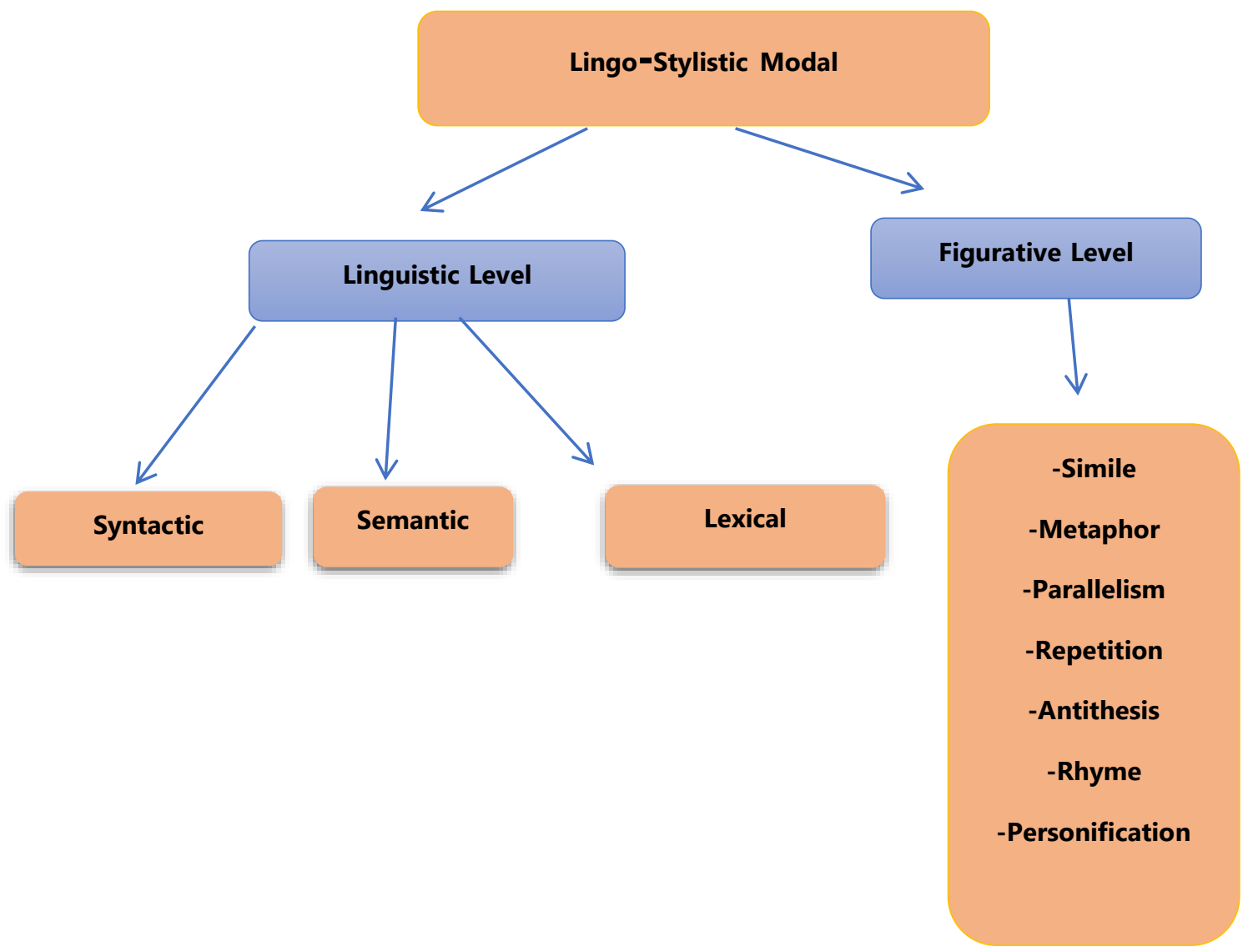

Figure 1: Linguo-stylistic Model of Analysis

\section{Data Analysis}

Twenty extracts are selected to constitute the data for this paper. However, two extracts are chosen to be representative examples due to the scope of this paper.

\section{Extract (1)}

وحتى الذين ألحقوهم بالحلة أو الرمادي أو بعقوبة كانوا يتذمرون ويدمدمون وهم يتوجهون إلى السيارات التي ستنقلهم إلى مقراتهم. هل " "كان أحد يتوقع رحلة إلى هاواين ؟

[Even those assigned to Hilla or Ramadi or Baquba grumbled to themselves as they headed towards the vehicles. Had they been expecting a trip to Hawaii?]

Analysis

After Zeina and conscripts arrived in Tikrit, they were sent to several cities: Hilla, Ramadi, and Baquba. They complained and rumbled as they headed for the cars that would take them to their headquarters... "What do they complain about? This is their job. They are translators, American recruits. What do they expect when they come to Iraq?" A recreation and tourism trip, for example, in this way, Zeina mocks those who complain. It should have been natural. "Why did they expect a trip to Hawaii?

Lexically, the dynamic verb يتذمرون (grumbled) which implies the two meaning sarcasm and complaint, is employed to make fun of the American soldiers who came to war but complained about their positions. The writer uses the abstract noun رحلة (trip) to describe the amount of ridicule and carelessness of the American army when they arrived in Iraq as if they were not in a war but on a joyful trip.

Grammatically, sarcasm is realized in this extract via the use of compound-complex sentence highlighted by the conjunctions الدقو حتى الذين ألحقوهم... كانوا ] و .... يتذمرون و يدمدمون] The aim of the use of this sentence is to reflect the state of soldiers who were complaining and grumbling while directing their faces towards their residences. This sentence shows their unpleasantness towards their being war men. 
Figuratively, this extract ends with a rhetorical question "هل كان أحد يتوقع رحلة إلى هاواي ؟ (Had they been expecting a trip to Hawaii?) to mock at the soldiers who were complaining about their status as if they were going on a trip to Hawaii. Indirectly these rhetorical questions indicate that they were going to a place of distastefulness. Semantically, Kachachi, through the meaning of this extract, is able to reflect her dissent towards America's behavior and their spiteful treatment of their soldiers.

\section{Extract (2)}

$$
\text { "أراني على الشاشين يرفعون شاريسة مخذذولة تحمل حاجياتها في كيس خاكي على الظهر ، ترتدي خوذة صلبة وبسطالا متربة وتسير وراء جنود " }
$$

[I see myself on the screen, a disillusioned saint carrying her belongings in a khaki backpack, wearing a hard helmet and dusty boots, and walking behind soldiers who raise the victory sign despite their defeat.]

\section{Analysis}

Zeina describes herself, after her return to America, as being like a deserted saint. It is ironic that she goes behind defeated soldiers and raises the banners of victory.

Lexically, Zeina creates a sarcastic contradiction between the abstract nouns النصر and مهزومين (victory and defeat) to describe her status of disappointment and sadness she experienced after her return to America. She is making fun of herself, how she has become like female soldiers serving the occupier of her country, claiming victory while they are defeated in many battles.

Grammatically, the writer manipulates a compound sentence which consists of two declarative clauses أراني على الشاشة... utilizing coordinating conjunctiong (and). و وتسير وراء جنود is used cohesively to combine these clauses to give more details concerning a contradiction about walking behind soldiers who raise the victory sign despite their defeat to ridicule herself and describe the sadness and disillusion that she felt upon her return to America.

Figuratively, the contrast between nouns مهزومين and النصر (victory and defeat) is employed to create a sense of sarcasm. Because she feels upset, she is going in front of defeated soldiers who raise the banners of victory. She wants to ridicule herself after being confident that the Americans came for freedom and not for killing and destruction. This situation provides a contrasting picture in which the defeated soldiers raise the flag of victory. Making use of the literal meaning of this extract, the author could provide a sarcastic sense of the events concerning soldiers raising the flag of victory.

\section{Conclusion}

Based on the findings of the study, the following conclusions have been made:

1. Contextually, American Granddaughter involves a setting in which an Iraqi woman lives in America, and after years she decides to return to Iraq as a translator in the ranks of the American army. Ziena, who witnessed the soldiers' mockery of Iraqi customs and traditions in Muharram, her naivety when she saw that America's presence in Iraq was the thread of freedom for Iraq, and many of the events of this satirical novel that the writer expressed indirectly are a reason to establish sarcasm in this novel.

2. At a lexical level, Arabic novel witnesses an increase in the use of nouns and verbs. In recording nouns, the writer uses various abstract nouns like رحلة (trip), مهزومين (defeat), النصر (victory) more than concert nouns and animal names like كلب (dog) to reveal ridicule and mockery. Concerning verbs, dynamic verbs like يتذمرون (grumbled), يغيرون (changed) take over a lot of extracts to take benefit of them in depicting sarcasm with little use of stative verbs. For adjectives, she uses emotional adjectives like (sad) sparingly in some excerpts. Yet, other types of adjectives like (evaluative, physical, psychological... etc. ) are rarely found in the data. Finally, adverb has no place in portraying irony or sarcasm, simply because with nouns, verbs, and adjectives, Kacahchi is able to depict sarcasm more effectively and more elaborately.

3. At the grammatical level, the four types of sentences (simple, compound, complex, and compound-complex) are exploited in the novel to express various sorts of meaning. Compound sentences have the largest share of use; they mostly rely on the conjunction $\mathbf{g}$ (and) to give more information and to combine two clauses to depict sarcasm and ridicule. Simple sentences are used relatively less than compound sentences to give a simple idea of mocking situations that occur in the Arabic novel. Kachachi also has recourse to complex sentences using the conjunction أذأا (if, when) and compound-complex sentences by using conjunction حتى + (and+ even). Functionally, American Granddaughter is realized in declarative sentences; no cases of imperative, exclamation, and interrogative sentences have been recorded in the data. This is owing to the fact that declarative sentences are preferred to express sarcasm in a very clear manner (in the form of statements). Through this type of sentence, certain information or ideas concerning mocking or ridiculous situations can be straightforwardly conveyed.

4. Figuratively, the writer highlights the use of symbolic and allegorical resources (i.e. rhetorical question, contrast, metaphor, repetition, simile, and metonymy) in the Arabic novel to portray a vivid picture of sarcasm. Metaphor has the largest use, like 
(A dog with two homes). Rhetorical questions like هلب أبو بيتين (Had they been expecting a trip to Hawaii?) are also observed in the data to express astonishment or emphasis associated with a sarcastic event. Simile such الأحجار في صالاته أشباح مبرمجة على الدهشة (broken stones in the halls) and (ghts doomed to eternal perplexity) and contrast like the contrast between الطرق الصغيرة (small ways) and نتائج كبيرة (immense results) are exploited to offer convincing images of ridiculous and sarcastic events. Finally, repetitions, like هيدا هيدرا (Hey da, Hey da ) and metonymy يميرة (the right) refer to the Ziena's hand, are the least used in the data. Perhaps, with this use, Kachachi wants to rid boredom and monotonous manner of conveying events. Semantically, Kachachi resorts to the literal meaning of the extracts to reflect the figurative meaning intended to echo sarcasm.

\section{References}

[1] Abrams, M. H. (2009). A Glossary of Literary Terms. London: Harcourt Brace Jovanovich College Publishers.

[2] Attardo, S. (1994). Linguistic theories of humor. New York: Mouton de Gruyter.

[3] Attardo, S., Wagner, M. M. and Urios-Aparisi, E. (Eds.) (2013). Prosody and humor (Vol. 55). New York: John Benjamins Publishing.

[4] Burton, F. (2009). A History of Sarcasm. (Ls12). United kindomLulu. com.

[5] Cardona, G. (2002). Indian linguistic studies: festschrift in honor of George Cardona. (vol.295). the university of Colorado. Motilal Banarsidass Publication.

[6] Carroll, N. (2014). Humour: A very short introduction. Oxford: Oxford University Press.

[7] Dauphin, V. (2000). Sarcasm in relationships. University of Pennsylvania: http://ccat.sas.upehn.edu/plc/communication/valerie.htm

[8] Fowler, R. (1991). Language in the News: Discourse and Ideology in the Press. London: Routledge.

[9] Galperin, I. R. (1977). Stylistics. Moscow: Higher School Press.

[10] Garmendia, J. (2018). Irony Key: Key Topics in pragmatics and Semantics. Cambridge: Cambridge University Press.

[11] Gurillo, L. R., \& Ortega, M. B. A. (Eds.) (2013). Irony and humor: From pragmatics to discourse (Vol. 231). New York: John Benjamins Publishing.

[12] Haiman, J. (1998). Talk is cheap: Sarcasm, alienation, and the evolution of language. Oxford: Oxford University Press.

[13] Hodgart, M. J. C. (1969). Die Satire (Vol. 42). New Brunswick. Hill Book company.Transaction Publishers.

[14] Leech, G. N. (1969). A Linguistic Guide to English Poetry. London: Longman Group Limited.

[15] Leech, G., and Short. M (2007). Style in Fiction. (2nded). London: Pearson Longman.

[16] Martin, R. A. (2007). The psychology of humor: An integrative approach Academic press.University of Western Ontario. London. Ontario, Canda N6A5C2

[17] McClennen, S., \& Maisel, R. (2016). Is satire saving our nation?: Mockery and American politics.

[18] McDonald, S. (1999). Exploring the Process of Interference Generation in Sarcasm: A Review of Normal and Clinical Studies. Brain and Language.

[19] Missikova G. (2003). Linguistic Stylistics. New York: Columbia University Press.

[20] Oxford, O. E. (2009). Oxford English Dictionary. Oxford: Oxford University Press.

[21] Quirk, R., Greenbaum, S., Leech, G. and Svarrtivik, J. (1985). A Comprehensive Grammar of the English Language. London: Longman.

[22] Riffaterre, M. (1983). Text Production. New York: Columbia University Press.

[23] Ruch, W., \& Ekman, P. (2001). The expressive pattern of laughter. In Emotions, qualia, and consciousness.San Francisco94143, USA $426-443$.

[24] Sperber, D. \& D. Wilson. (1981). Irony and the use-mention distinction. In Radical Pragmatics, ed. P. Cole, 295-318. New York: Academic Press. 1986/95. Relevance. Communication and Cognition. Oxford: Blackwell.

[25] Stieger, S., Formann, A. K., \& Burger, C. (2011). Humor styles and their relationship to explicit and implicit self-esteem. Personality and Individual Differences, 50(5), 747-750.

[26] Toplak, M. (2000). On the uses of sarcastic irony. Journal of Pragmatics, 32, 1467-1488

[27] Verdonk, P. (2002). Stylistics. Oxford: Oxford University Press.

[28] Weisfeld, G. E. (1993). The adaptive value of humor and laughter. Ethology and sociobiology, 14(2), 141-169.

[29] Widdowson, H.G. (1975). Stylistics and the Teaching of Literature. London: Longman Group Limited. 